\title{
The Church in a Pluralistic World: The Public Vision of Ressourcement
}

\author{
Gabriel Flynn \\ School of Theology, Philosophy, and Music, Dublin City University, D09N920 Dublin, Ireland; \\ gabriel.flynn@dcu.ie
}

Received: 13 August 2019; Accepted: 16 October 2019; Published: 24 October 2019

check for updates

\begin{abstract}
The dual concern of this article is to present the vision of the church articulated by the renowned generation of Catholic ressourcement thinkers in the mid-twentieth century, and to demonstrate its continued fecundity in the pluralist, multi-cultural context of contemporary western society. It seeks to contribute primarily to ecclesiology, while also providing historical and social commentary with respectful suggestions for its relevance to present-day ecclesiology. The article provides an interpretative framework for understanding ressourcement with reference to its philosophical foundations and the vision of its founders. Its aims are, first, to articulate the role of ressourcement in the modern context and, secondly, to document the genesis and emergence of that movement's perception of the church's mandate in the world, based on an essential return to the sources of Christianity. The paper presents the public vision of ressourcement ecclesiology in two parts, drawing principally, though not exclusively, on the work of the two leading intellectual orders of the Catholic Church at the time of its formulation, namely, the Dominicans and the Jesuits of France. In this paper, I limit myself to the French-speaking Jesuits and Dominicans and do not refer to Rahner, Semmelroth, Schillebeeckx or Schoonenberg.
\end{abstract}

Keywords: ressourcement; pluralism; secularization; public vision; Congar; Chenu; de Lubac; Saulchoir; Fourvière

\section{The Future of Ressourcement}

The primary focus of this paper is the Catholic Church's engagement with the world in the twentieth century, with particular attention to France. It is also concerned with the application of the ressourcement vision in the pluralist, multi-cultural context of contemporary western society. It seeks to demonstrate the continued relevance of ressourcement ecclesiology by reference, first, to Yves Congar's vision of the church, notably, his theology of the laity and his proposals for church reform; secondly, to Marie-Dominique Chenu's innovative contribution to Thomism and to the renewal of Catholic theology; and, thirdly, to Henri de Lubac's and Jean Daniélou's patristic revival, for its perennial appeal and relevance. In 2019, Éditions du Cerf, Paris published the 600th volume in the acclaimed Sources Chrétiennes Series, an important milestone in the history of ressourcement. ${ }^{1}$ The article provides an interpretative framework for understanding ressourcement with reference to its philosophical foundations, ${ }^{2}$ and the vision of its founders whose ecumenical theology and outreach

1 See <https://www.editionsducerf.fr/librairie/collections/39/sources-chretiennes/200>.

2 See (Fields 2014). Here Fields articulates a careful response to an awkward question that presents itself concerning the philosophical underpinnings of ressourcement. Following Aidan Nichols, he argues that the polemic between Thomism and ressourcement concerns integrating patristic insights about subjectivity and event into a sound metaphysics. He presents the case for a continuing dialogue between ressourcement and Thomism for the benefit of the contemporary world. See also (Bedouelle 2010). 
had a transformative effect on the Catholic Church and its relationship with the other Christian Churches. Its specific aims are, first, to articulate the role of ressourcement in modern society which brings us to the heart of the entire ressourcement project, and, secondly, to document the genesis and emergence of that movement's perception of the Church's mandate in the world based on the essential return to the sources of Christianity. The accomplishment of the Catholic Church's mission in secular society, even in times of religious freedom and tolerance, requires cultural sensitivity, diplomatic acuity in relation to the civil authorities and civic society in its totality, including governments, local authorities, health, and higher education where theology exercises an inimitable role. ${ }^{3}$ The successful formulation and enactment of a public vision for Christianity in present-day society that is no longer governed by Christian principles, calls for confidence in the Word, a spirit of humility, and fortitude in witness. As Hans Urs von Balthasar remarks with spiritual and cultural perspicacity: 'The temptation to negation and despair is so great, it presses so heavily upon those who still remain sensitive to the question of the meaning of life that they need to use all their strength to go against the stream. It is here that the thought of the Church at prayer comes to the rescue. ${ }^{4}$ Finally, a consideration of 'communion ecclesiology' is important for understanding the public vision of ressourcement in its totality. The concluding section of this article will, therefore, assess communion theology, an offshoot of ressourcement, in a way that shows its relevance and effectiveness for ecclesial reform and the rejuvenation of secular society. ${ }^{5}$ The paper gives rise to important sociological questions, including the dynamics of unbelief and secularization since the 1960s, as well as the complex and vital theological question of tradition, its content, and social context within the church. ${ }^{6}$ I have addressed the question of tradition in detail elsewhere, while secularization/unbelief today requires additional work beyond the scope of this article. ${ }^{7}$ Much ink has already been spilt on the Council's history and reception, and further multi-volume series are planned. ${ }^{8}$ The present paper will not, however, attempt a social history or commentary of the period since Vatican II, a task that is beyond the confines of this article.

In the first half of the twentieth century, a broad confluence of intellectual and spiritual movements of renewal associated principally with the French- and German-speaking countries blossomed as part of a profound Catholic theological revival. ${ }^{9}$ Nouvelle théologie arose within European Catholicism during a period of profound change and crisis and has received significant attention from scholars in recent years. ${ }^{10}$ The appellation nouvelle théologie, a term originally used in a disparaging manner to describe the work of leading French, Belgian, and German theologians for a renewal of theology and church by means of a return to the biblical, patristic, and liturgical sources, eventually became known as ressourcement. The dominant streams of renewal at the centre of the movement were in the domains of liturgy, scripture, and patristics. Historians and exponents of ressourcement have documented the movement's historical evolution. ${ }^{11}$ Roger Aubert provides a comprehensive account of ressourcement in his authoritative historical study La Théologie Catholique au milieu du XXe siècle. ${ }^{12}$ The early part of the twentieth century also witnessed a renewal in ecclesiology and a new focus on the church's mission. ${ }^{13}$ In the course of its history, the French church has displayed remarkable creativity in the face of crisis. The challenges facing the church there in the 1930s and the 1940s were immense. This is attested to by the emphatic declaration of Henri Godin in 1943, concerning the state of the French church: 'Yes, here

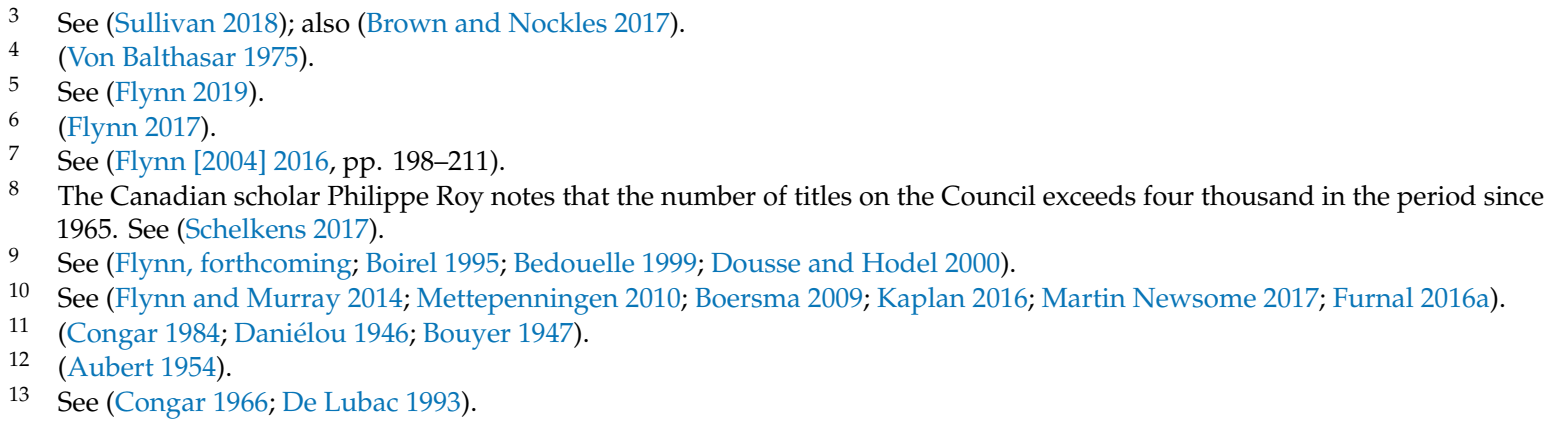


we are indeed in pagan territory.' ${ }^{\prime 14}$ The response of the leading ressourcement intellectuals following their liberation was to address the challenge of renewal and revitalization in a de-Christianized nation with courage and determination.

Ressourcement encompassed Belgium and Germany and included such thinkers as Émile Mersch, Odo Casel, Romano Guardini, Karl Adam, and Anselm Stolz. ${ }^{15}$ But its undisputed centre was France, where it was led principally by luminaries of the Jesuit (Lyon, Fourvière) and Dominican (Saulchoir, Paris) faculties of theology. They were the Dominicans Marie-Dominique Chenu (1895-1990), Yves Congar (1904-1995), Dominique Dubarle (1907-1987), and Henri-Marie Féret (1904-1992), and the Jesuits Jean Daniélou (1905-1974), Henri Sonier de Lubac (1896-1991), Henri Bouillard (1908-1981), and Hans Urs von Balthasar (1905-1988) who, under the influence of Adrienne von Speyr, left the Society of Jesus in 1950 in order to found a 'secular institute' for lay people. This brilliant and innovative group, united by a lively spirit of fraternity, helped to create what Chenu called 'the golden age of Christianity and creative civilization.' ${ }^{16}$ Among the new initiatives were the movement for the reform of the liturgy, Centre de Pastorale Liturgique (1943), followed by the launch of the journal $L a$ Maison Dieu (1945); the return to biblical and patristic sources, exemplified especially in the Sources chrétiennes series, and a second patristic series of Latin texts 'Corpus Christianorum', 17 founded by Eligius Dekkers in 1947 at Turnhout (Belgium) to which was added a Greek series in 1977 with Marcel Richard as editor; the renewal of ecclesiology, demonstrated by the establishment of the Unam Sanctam series; and the realization of the church's missionary task epitomized in Godin's famous book $L a$ France: pays de mission?; the encyclicals of Cardinal Emmanuel Suhard; the worker-priest movement; and new missionary strategies including the Young Christian Worker and Young Christian Student movements. ${ }^{18}$ As Congar remarks: 'Anyone who did not live through the years 1946 and 1947 in the history of French Catholicism has missed one of the finest moments in the life of the Church.' ${ }^{19}$ De Lubac highlights the spirit of hope, creativity, and originality that pervaded this buoyant period of spiritual and intellectual fecundity in the history of the French church with Chantiers de Jeunesse, Youth Work Camps where he gave lectures on 'The Church in the Face of the World Crisis', and Cahiers du Témoignage chrétien, a weekly French newsletter founded in Lyon in 1941 by Pierre Chaillet and Henri de Lubac in which they presented a principled opposition to Nazism as part of a Jesuit resistance movement. $^{20}$

The ressourcement project was severely criticized by Marie-Michel Labourdette, ${ }^{21}$ as well as by Réginald Garrigou-Lagrange. ${ }^{22}$ In an atmosphere of suspicion and controversy, Pope Pius XII published Humani Generis on 12 August 1950 with its condemnation of the nouvelle théologie and catastrophic results for the leaders of that movement. ${ }^{23}$ The election of John XXIII and his decision to convene an ecumenical council resulted in a dramatic change of fortune for the leading ressourcement intellectuals, most notably Congar and de Lubac, that effectively catapulted them to the centre from where they orchestrated a program of reform of the Catholic Church with dramatic consequences both good and bad. Joseph Folliet (1903-1972), a lay expert at Vatican II and a friend of Congar, Jacques Maritain (1882-1973), and François Mauriac (1885-1970) the Nobel Laureate (1952) and symbol of the Résistance,

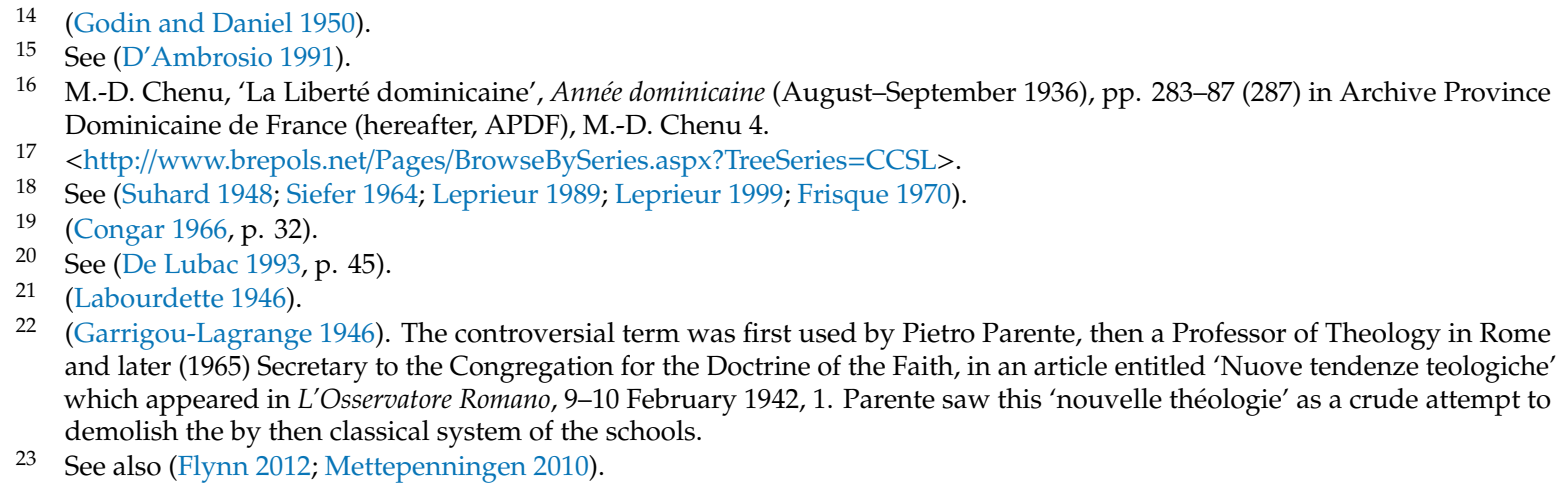
and later (1965) Secretary to the Congregation for the Doctrine of the Faith, in an article entitled 'Nuove tendenze teologiche' which appeared in L'Osservatore Romano, 9-10 February 1942, 1. Parente saw this 'nouvelle théologie' as a crude attempt to demolish the by then classical system of the schools.

23 See also (Flynn 2012; Mettepenningen 2010). 
provide a contemporaneous, moving account of the epoch as one of 'intellectual decadence, images of what is left of a solid and brilliant past, like the works of Father de Lubac, Father Congar, Rahner, and Karl Barth. ${ }^{24}$ The leaders of ressourcement made a decisive contribution to the reforms of the Second Vatican Council (1962-1965), and their thought is enshrined in the Council's pivotal documents. ${ }^{25}$ The Council provided a public engagement with modernity, one that is replicated anew in each succeeding generation. Recent research by Joshua Furnal of Radboud University, the Netherlands shows that Søren Kierkegaard's vision of a more social and culturally inclusive model of the church had a significant impact on the ressourcement theologians and contributed to the achievement of Vatican II. ${ }^{26}$ As he writes: 'I would like to make an alteration to the story that is often told about the significance of the ressourcement movement before the Second Vatican Council—namely that, before 1962, European Catholicism was in a kind of dark age that was anti-modern and anti-Protestant. ${ }^{27}$ Furnal asserts that in the period before Vatican II, there was significantly more Catholic engagement with modern Protestant thought than had previously been assumed. ${ }^{28}$ In a survey of key ressourcement thinkers, he demonstrates how Kierkegaard contributed to the rehabilitation of Catholic theology by Daniélou, aided Congar in his understanding of the complexity of modern culture, and contributed to de Lubac's engagement with modern thought. ${ }^{29}$ The public vision of ressourcement ecclesiology is presented here in two parts, drawing principally on the work of the leading intellectual orders of the Catholic Church at the time of its formulation.

\section{The Public Vision of Ressourcement Ecclesiology: From Contemplation to Action}

\section{(I) Le Saulchoir: A Dominican School of Theology}

By the mid-twentieth century, as part of its emergent relationship with the modern world, the Catholic Church began to engage tentatively in ecumenical and inter-religious dialogue. ${ }^{30}$ Vatican II became the catalyst for change on a global stage through its vast program of reform and renewal. ${ }^{31}$ The achievement of the ressourcement theologians lies principally in their capacity to engage with modernity, thus ensuring a place, however modest, for the Christian Church in the public domain. ${ }^{32}$ Turning first to the role of the French Dominicans in the formulation of the public vision of ressourcement ecclesiology, one encounters 'an organization in the service of liberty. ${ }^{\prime 33}$

A master of contemplation in action, Marie-Dominique Chenu was the quintessence of what Thomas Aquinas considered the spirit of the Dominican order, namely, 'to contemplate, and to share with others what one has contemplated. ${ }^{34}$ He points to an antinomy in the art of contemplation: 'We are certainly passive with regard to contemplation; but in this passivity there is maximum activity. ${ }^{\prime 35}$ Like his Dominican and ressourcement confrères, Chenu was deeply committed to the discovery of truth. As he opines: 'God accepts to be the food of our spirit on condition that the truth actually becomes the life of our spirit. ${ }^{\prime 36}$ Convinced that contemplation is the major problem, he held that Christians advance in perfection to the extent to which they 'have a fuller sense and a more explicit control of the interior life as a whole. ${ }^{37}$ He urged theologians to strive for spiritual freedom by doing

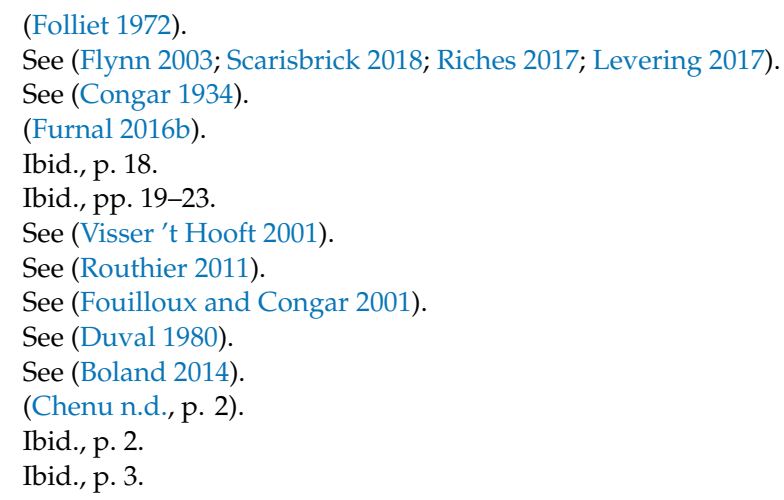


theology in a spirit of disinterestedness and, like innocent children, to attain the whole gamut of gospel virtues. 'Theology is audacious, because, in the self-forgetfulness of contemplation, it is pure; it can have every boldness as long as it is pure-the science of the children of God. ${ }^{38}$ A noted historian and medievalist, Chenu had a rich sense of the interconnectedness of things and worked unrelentingly for the transposition of theology into the social domain for the betterment of humanity, in particular, of those at the lower echelons of society. ${ }^{39}$ At a dogmatic level, Chenu's vision of the relationship between the Church and the world rests on the incarnation as the pivotal foundation of his theology and social mission. As he remarks in an interview given in 1965: 'I felt very strongly the exigencies of the Incarnation. If Christianity is about God incarnate in matter, the divinisation of man implies that it include matter. ... Humanisation is already a capacity for divinisation. ${ }^{40}$

Chenu was a man ahead of his time who made an original contribution in three domains, first, as a theologian and social analyst; secondly, as a social activist whose rich program of public engagement embraced a wide spectrum of modern society and contributed to a new engagement of the church with the world; and thirdly, as a medievalist whose achievement was internationally recognized, he demonstrated that it is both necessary and enlightening to read theology in historical context. ${ }^{41}$ He collaborated with the Catholic philosopher Étienne Gilson in the establishment of an Institute for Medieval Studies at Montreal in French-speaking Canada. ${ }^{42}$ In 1961, in his programmatic 'La fin de l'ère Constantinienne', Chenu points to the renewal of Western Christianity and its transformation into a global church. In his new vision of the relationship between Church and state, Chenu envisaged the Christianization of the world as the old mutually beneficial alliance between church and state of the Constantinian era came to a close. As he writes: 'What is at stake is not the Church building for itself a Christian world of its own alongside "the world," but proceeding to Christianize the world in the process of being built. ${ }^{43}$

Perhaps more than any other, Chenu provided the inspiration, vision, and leadership for the establishment of Le Saulchoir as the leading Catholic school of theology in France at mid-century. His most influential work is undoubtedly Une école de théologie: le Saulchoir. He envisioned Le Saulchoir 'as a centre of reflection and theological/historical research, faithful to Thomist inspiration as well as possessing a capacity to engage with the problems confronting Christians in contemporary culture. ${ }^{44}$ As Regent of Studies, Chenu committed himself and the faculties of Le Saulchoir to the support of the nascent Young Christian Workers. He saw a close connection between his 'work situating St Thomas in history, and these encounters with people engaged in apostolic, even social, warfare. ${ }^{45}$ His ground-breaking work on Aquinas is acclaimed by scholars for its breadth of perspectives showing his engagement with the world and human history, which he viewed as having been dramatically changed through the incarnation. 'Aquinas and His Role in Theology is an important book by one of the greatest contemporary interpreters of St. Thomas Aquinas', as Paul Philibert reminds us in his 'Translator's Introduction', where he also notes what Chenu himself said: 'It is possibly the best thing I have ever written. ${ }^{46}$ Unsurprisingly, Chenu viewed himself as 'all mixed up in contemporary issues,

38 (Chenu 1937); see also (Vangu 2007).

39 See 'Marie-Dominique Chenu: Moyen-Âge et Modernité', Colloque organisé par le Département de la recherche de l'Institut catholique de Paris et le Centre d'études du Saulchoir à Paris, les 28 et 29 octobre 1995 sour le présidence de Joseph Doré et Jacques Fantino in Les Cahiers du Centre d'Études du Saulchoir V, Paris: Cerf 1997. Source: 'Marie-Dominique Chenu, A'. Archives of the Centre for the Study of the Second Vatican Council, Faculty of Theology and Religious Studies, Catholic University of Louvain (KU, Leuven).

40 Chenu, 'Une théologie pour le monde', no 31, 1967, 17; cited in (Potworowski 2001).

41 Chenu, 'La "Doctrine Sociale" de l'Eglise', Foi et developpement (1981), 1-4, source: 'Marie-Dominique Chenu, A', Archives of the Centre for the Study of the Second Vatican Council, Faculty of Theology and Religious Studies, Catholic University of Louvain (KU, Leuven).

42 (Duquesne and Chenu 1975); also (Murphy 2004).

43 (Chenu 1961); see also (Zamagni 2011).

44 (Alberigo 1985)

45 (Duquesne and Chenu 1975, pp. 57-58); also (Kelly 2016).

46 (Philibert 2002). 
eager to get involved in the most sensitive pastoral problems of the world and of the Church' as well as being deeply committed to 'the mutual engagement between the patient and scholarly pursuit of theology and the apostolic impatience of the Gospel. ${ }^{47}$ Citing Daniélou's influential essay 'Les orientations présentes de la pensée religieuse', ${ }^{48} \mathrm{~A}$. N. Williams opines: 'There is a certain commonality between what the Jesuits of Fourvière were dissatisfied with and what Bouillard's and Chenu's work on Aquinas sought to correct: a monolithic neo-Thomism which had become as remote from contemporary concerns and the needs of the twentieth-century church as it was arguably distant from the spirit of Thomas himself. ${ }^{49}$ Indeed, Chenu's experience with the Young Christian Workers/Jeunesse ouvrière chrétienne (JOC) provided the key to his entire mission and kept him in close contact with those at the head of his next missionary project. He was closely involved with the Mission de France/Mission de Paris along with Suhard and Godin. This work was not without its difficulties and during meetings of Mission de France/Mission de Paris, there were 'painful tensions' between Godin who advocated for a general mission to the working class of France and Georges Guérin, the founder of the JOC in France, who, according to Chenu, viewed everything in terms of the Young Christian Workers.

A veritable champion of openness, Chenu held that 'one cannot be prepared intellectually to welcome new ideas if socially and institutionally one remains closed in on oneself. ${ }^{50}$ His work would ultimately yield a universal harvest on a global scale. Yves Congar accentuates his leadership skills and ecumenical acumen in a generous tribute as follows: 'Father Chenu, an incomparable inspiration to a whole generation of young Dominicans, spoke to us on one occasion of the "Faith and Order" Movement during his course on the history of Christian doctrine, as he also spoke of the Lausanne Conference and of Möhler. ${ }^{51}$ In an interview given in 1975, Chenu stated that he and Congar effected a rediscovery of Johann Adam Möhler (1796-1838), the German ecclesiastical historian and theologian of the Church. Möhler, and the Roman Catholic School of Tübingen, introduced a principle of renewal into nineteenth-century theology with a conception of faith, which integrates its historical, psychological, and pastoral dimensions. Möhler's highly original, patristics-based ideas on the church, with complementary pneumatological and Christological elements, penetrated Catholic ecclesiology and contributed to the reforms of Vatican II. In order to transcend the juridical idea of the church, Congar, together with Chenu and Henri-Marie Féret, embarked on an enterprise to eliminate 'baroque theology', 52 a term they coined to describe the theology of the Counter-Reformation.

Chenu was ever the man of action. With his colleagues and friends, most notably Congar, he worked assiduously in the midst of an evidently complex and conflictual epoch for renewal among the worker priests, the Young Christian Worker and Young Christian Student movements, the secular clergy, atheists and others outside the church. As he remarked in February 1965: 'Finding myself with curates, priest-workers, parishioners, bishops, even unbelievers, I have always considered these encounters as a test of the truth of our labor, and a guarantee of its evangelical source. ${ }^{.53}$ It should not be forgotten, however, that Chenu's vision for the church in the public square as well as his bold reformulation of Catholic theology encountered fierce opposition within his order, in Paris and Rome, including from Réginald Garrigou-Lagrange who supervised his doctoral dissertation, Michael Browne, Rector of the Angelicum University and future Master of the Dominican order, as well as Mariano Cordovani, the pope's personal theologian; all of whom were stout defenders of Thomism and fierce enemies of the nouvelle théologie. In theological terms, Chenu's lasting achievement, as Fergus Kerr has shown, was to challenge directly and from within, the standard reading of the Summa

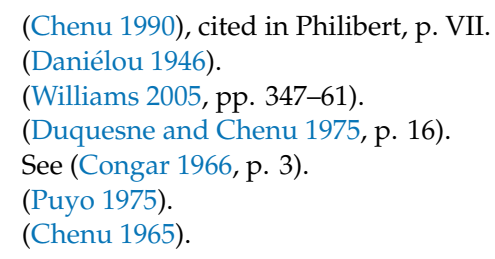


Theologiae. ${ }^{54}$ His most enduring contribution, however, lies in the domain of practical theology in the secular, pluralist context of modern society, as Claude Geffré, speaking on behalf of the French Dominican publisher Éditions $d u$ Cerf, has illustrated in a wide-ranging work. ${ }^{55}$ Indeed the first half of Geffrés L'hommage différé au Père Chenu consists of recollections about Chenu's théologie engagé, including his theology of work, collaboration with the Catholic youth organizations, and his profound commitment to mission. In the laudatory remark of Étienne Gilson, 'A Father Chenu-there is only one such every hundred years! 56

In Yves Congar, we encounter the foremost French theologian of the twentieth century whose articulation of a new ecclesiology changed the face of the global church forever. He contributed more than any of his countrymen to the public vision of ressourcement for a pluralistic world. While his research on unbelief brought him to the forefront in the late 1930s in France, it was his remarkable contribution at the Second Vatican Council (1962-1965) that earned him international acclaim and pride of place in the history of twentieth-century French Catholicism. ${ }^{57} \mathrm{He}$ was a champion of church reform through a return to the sources, and he devised a vast program of renewal in ecumenism, pneumatology, the theologies of ministry and laity, and the application of the rich resources of tradition to the current problems of the Church. ${ }^{58}$ His reformist program, by presenting an ideal for the Church in its origins and with regard to eschatology, manifests a concern for the needs of the young and thus displays pastoral sensitivity, which, by virtue of its sources, is unique. As he writes: 'The young are for a Jesus Christ who is a "man for other men". The only "Church" they will have is the collectivity of those who live the Gospel as a message of liberation and human brotherhood. ${ }^{59}$ Congar, the consummate ecumenist, had also worked tirelessly in the Catholic Conference for the advancement of ecumenical questions. ${ }^{60}$

Congar's theology of the church is for the world and at the service of all. His view of the relationship between the church and the world is one of dependency: 'The Church and the world need one another. The Church means salvation for the world, but the world means health for the Church: without the world there would be danger of her becoming wrapped up in her own sacredness and uniqueness. ${ }^{61}$ In a period characterized by a new concern for the poor and an urgent need to define the relationship between church and world, Congar identified the latter as essential for a successful reform of the church. With notable perceptiveness, he observes: 'The pastoral activities of the Church no longer had influence on the great mass of people, in particular on the most hardened and the most dynamic. ${ }^{\prime 62}$ When Christianity is reduced to mere ritualism, it changes nothing. Congar's response to the demands of believers and of the world was to propose a self-critique for the Church, thus making reform necessary.

A reconstruction of Congar's vision of the church shows that a renewed ecclesiology forms an essential theological basis for a renewed church. In November 1935, the Dominican journal La Vie intellectuelle announced the foundation of a new book series entitled Unam Sanctam (Congar 1939), with Congar as director, that was to become an ecclesiological library running to seventy-seven volumes. Its aim was to present a multi-faceted study of the mystery of the Church while also, at Congar's insistence, always keeping in mind its organic unity. Congar was able, under the auspices of this new series, to harness the reforming energies of some of the most brilliant French and European theologians for the renewal of the Church.

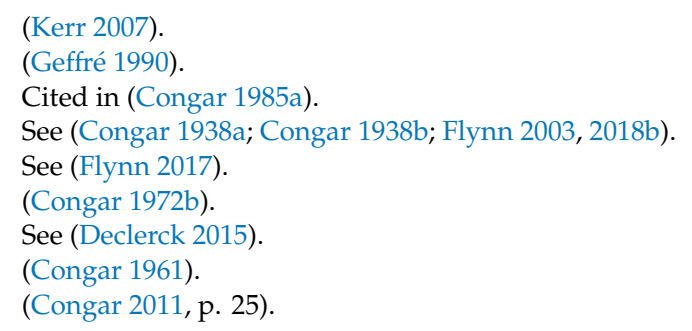




\subsection{The Church: A Cause of Unbelief}

Congar's 1935 study on unbelief, 'The Reasons for the Unbelief of our Time: A Theological Conclusion' is important for a correct understanding of his most significant projects in ecclesiology. It was precisely his findings regarding the causes of unbelief that moved him to initiate the Unam Sanctam collection, dedicated to the renewal of ecclesiology, and to write his most important works on the Church. ${ }^{63}$ His study on unbelief provides the raison d'etre for his entire program of ecclesiological reform. In 1967, he described the basic findings of his study of unbelief in a way that brings us to the heart of the matter: 'This led to the conclusion that as far as this unbelief depended on $u s$, it was caused by a poor presentation of the Church. At that time, the Church was presented in a completely juridical way and sometimes even somewhat political'. ${ }^{64}$

Congar identified two causes of contemporary unbelief. First, the substitution of a Christian way of life with a purely human spirituality. This was part of the movement towards secularization that began in the fourteenth century with the passing of culture into the hands of the laity and spread inexorably affecting the professions and social life. All human activities were gradually reconstituted outside of the Church and independent of the Christian faith. The second reason for contemporary unbelief concerns the response of the church to secularization and its own changed status. In the face of the new, secular-human spirituality, the church was reduced to a fenced-off, special, and anti-progressive group. ${ }^{65}$ The failure or inability of the church to respond positively to the problem of the separation between faith and life is an important factor in explaining the phenomenon of continued widespread unbelief in contemporary society. The challenge for the church is to unite faith and life and to show that faith offers the possibility of attaining a degree of understanding of the true meaning of life. This is precisely what Congar was attempting to achieve by linking faith in Christ to the human search for happiness and meaning in life.

The movement towards secularization was sustained and animated by a certain human, or what Congar prefers to describe as humanitarian mysticism. He identifies the construction of a spiritual whole, outside and independent of Christianity, and the church's defensive reaction as the main reasons for the hiatus between faith and life in the world and the principal cause of unbelief. In his 1978 study Église Catholique et France Moderne, Congar presents the mission of the church to the world in historical perspective with Vatican II as the essential point of reference. He restates an ecclesial vision based on communion that is both conciliar and collegial. His ideal view of the bishop and episcopal collegiality is clear evidence of how much remains to be realized in the global vision for church renewal articulated at Vatican II. ${ }^{66}$

There are two further elements of Congar's ecclesiology on which I wish to comment briefly, namely, his theology of the laity and his principles for church reform since they point to the enduring relevance of his vision of the Church. For Congar, the central problem, one that supersedes the sum of the questions involved in a theology of the laity, concerns the provision of a theology of the church in all its dimensions. In other words, the theology of the laity presupposes a complete theology of the church. As he writes succinctly: 'There can be only one sound and sufficient theology of laity and that is a "total ecclesiology".'67 The vocation of the laity is to be the church in its fullness. This is perhaps the most original aspect of Congar's contribution to the theology of the laity. In the final analysis, the replacement in his theology of the laity of the notion of 'priesthood/laity' by the concept of 'ministries/modes of community service', founded on the re-discovery of the principle of the co-responsibility of all the baptised, boldly asserts that the mission of the Church is a responsibility

63 See (Congar 1962b).

64 See (Granfield 1967).

65 See (Congar 1938a).

66 (Congar 1978, p. 98). Congar displays a peculiarly French preoccupation with the meaning of the terms laïcisme (secularism) and laïcité (religious neutrality of state education). See (Williams 2018, pp. 133-57).

67 (Congar 1985b); see also (Beal 2014). 
shared by all. ${ }^{68}$ Likewise, Congar's vision for church reform constitutes a charter for ecclesial renewal. In Vraie et fausse réforme dans l'Église (1950), his magnum opus on reform and one of his most influential works, he describes the conditions for a true reform of the Church, which he says can be reduced to four principles: (i) the primacy of charity and the pastoral; (ii) to remain within the communion of all; (iii) patience; respect for delays; (iv) a true renewal by a return to the principle of the Tradition. ${ }^{6}$ Whether or not we agree with Congar's analysis of reform, it is necessary to understand his point of view as a reformer, for it is plain, as the history of the Second Vatican Council shows, ${ }^{70}$ that his greatest achievement is to have formulated a theory of Church reform that was successfully acted upon at that Council. It is indusputable that the genius of Congar's plan of action, as presented in Vraie et fausse réforme dans l'Église, lay in the proposed dialectical relationship between unity and reform in the Church, and so we are justified in speaking of its ultimate success at Vatican II. His Journal of the Council demonstrates unambiguously that the council was grounded in the lived experience of the church and the modern world. In an entry on 7 December 1965, he wrote poignantly: 'Looking at things objectively, I have done a lot to prepare for the Council, to elaborate, to articulate ideas that were adopted by the Council.'

In the history of Vatican II, Congar is inextricably linked with de Lubac; both were synonymous with the nouvelle théologie/ressourcement movement, the council and its program of renewal, as well as its reception, enactment, and ultimate disenchantment. ${ }^{71}$

(II) Lyon-Fourvière: A Jesuit vision of the Church in the Modern World ${ }^{72}$

Henri de Lubac, the leading Jesuit intellectual of the era, was born at a time of profound change in relations between church and state in France. The laï/secular republican government of Pierre Waldeck-Rousseau (1846-1904) launched an attack on the influential regular clergy that reached its zenith during the term of office of the next government (June 1902-January 1905) when, under the premiership of Emile Combes (1835-1921), up to ten thousand religious-run schools were closed in the course of 1903-1904. Combes enacted legislation for the strict separation of church and state, which resulted in the expulsion from France of some twenty thousand religious. ${ }^{73}$ In the face of these complexities, the leading intellectual religious orders displayed a remarkable capacity for innovation and adaptation and made a vital contribution to the blossoming of the Catholic intellectual Aufklärung of the day in which the Jesuits of Lyon played a leading role.

The origins of the 'Lyon School' may be traced to this tumultuous period, as Étienne Fouilloux has demonstrated with alacrity. 'At the beginning of the twentieth century, when anticlericalism reigned triumphant and the Modernist crisis was brewing, its enemies from both the left and the right thought they had identified another 'Lyon School', a small, informal group of Catholic figures who had been brought together, according to Bernard Comte, by a threefold concern. First, the rejection of a brutal confrontation with the lay republic; second, "the demand for free enquiry and a critical spirit" within the ecclesial domain; and third, "the desire for a purified religion which went beyond narrow confessionalism". ${ }^{74}$ This project did not survive. It was followed by a new 'Lyon School' in the inter-war period.

In 1926, the Jesuit Theologate of the provinces of Lyon and Paris returned to Fourvière for almost half a century. The historian Limore Yagil depicts Fourvière as a leading centre of theological research in the following laudatory terms: 'With its Catholic faculties, the Jesuit Scholasticate Fourvière, the interdiocesan seminary, but also the Catholic teachers at the university, Lyon's influence extended far

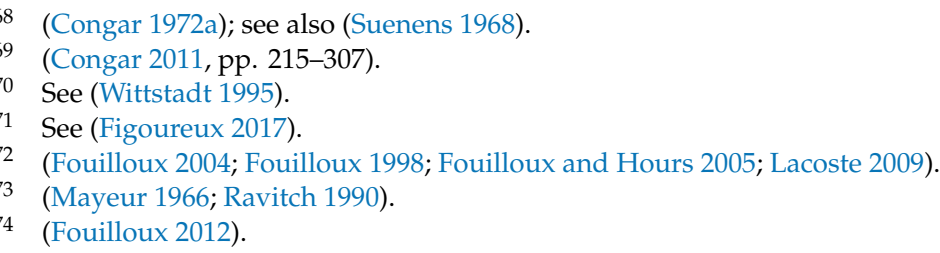


beyond the borders of the country. Since 1932, the Fourvière was known as a prestigious school of theology in French Catholicism. ${ }^{75}$

In 1932, Victor Fontoynont became Prefect of Studies in the Fourvière Theologate and helped by his circle known as 'the Fontoynont group', which included Gaston Fessard, Henri de Lubac, and Yves de Montcheuil, he founded two highly influential book series. The Théologie series, dedicated to the 'renewal of the Church', was launched in 1944 with Fr Henri Bouillard as its first secretary. Bouillard said that the twofold objective of the project was 'to go to the sources of Christian doctrine, to find in it the truth of our life. ${ }^{76}$ Sources chrétiennes, a bilingual collection had been launched two years earlier and was published by Éditions du Cerf, under the general editorship of de Lubac and Daniélou. It is the single greatest achievement of Fourvière and its most enduring contribution to ressourcement, Catholic theology, and the church. ${ }^{77}$ De Lubac elucidates the importance of Sources chrétiennes for renewal as follows: 'Each time, in our West, that Christian renewal has flourished, in the order of thought as in that of life (and the two are always connected), it has flourished under the sign of the Fathers. ${ }^{78}$ The series has contributed to making the Fathers the normal spiritual milieu of theologians and the educated laity. ${ }^{79}$ John Courtney Murray (1904-1967), the American Jesuit and public intellectual, ${ }^{80}$ an acclaimed contributor to church-state relations in the USA and a champion of religious liberty, ${ }^{81}$ describes the success of Sources chrétiennes as follows: 'We are all familiar with that definite, if undefinable reality known ... as a "climate of opinion." And we know, too, that in the patristic climate of opinion, the uninitiated rather tends to gasp for breath. It is to this problem and its solution that the recently inaugurated series of patristic texts, Sources chrétiennes, directly addresses itself, with altogether remarkable success. ${ }^{82}$ Along with his confrères Jean Daniélou (1905-1974), Henri Bouillard (1908-1981) and Balthasar, de Lubac was part of the 'cercle de Fourvière', the renowned generation of European ressourcement theologians who made an outstanding contribution to the twentieth-century renaissance in Catholic theology. De Lubac's major concerns were not formulated randomly, as may be seen from his earliest works Catholicisme: les aspects sociaux du dogme (1938), Corpus Mysticum (1944), and Surnaturel (1946). An important objective of this article is to document the indispensable relationship between the church and world in de Lubac's thought, the pinnacle of his ecclesial vision, in order to illuminate his important contribution to church-state relations. De Lubac perceived this vital relationship as paradoxical and conflictual: 'Again paradox; the mystical Bride, the Church with the hidden heart, is also a being very much visible among the beings of this world. [ ... ] There is-disastrously — a rivalry between the two and a more or less unceasing struggle, each complaining of the encroachments of the other: 'Nothing is more unstable and precarious than their equilibrium.' ${ }^{83}$ The Oxford philosopher Martin C. D'Arcy lauds de Lubac for his depiction of the church in Catholicism as 'a universal society which refuses nothing human and whose members are truly persons when joined together in the closest interdependence. ${ }^{\prime 84}$

It should be noted that for de Lubac everything points to the Eucharist. ${ }^{85}$ In common with other theologians, de Lubac views the church as most fully itself in the celebration of the Eucharist. ${ }^{86}$ He articulates his hypothesis succinctly in Corpus Mysticum. 'The Church and the Eucharist make each other, every day, each by the other: the idea of the Church and the idea of the Eucharist must likewise

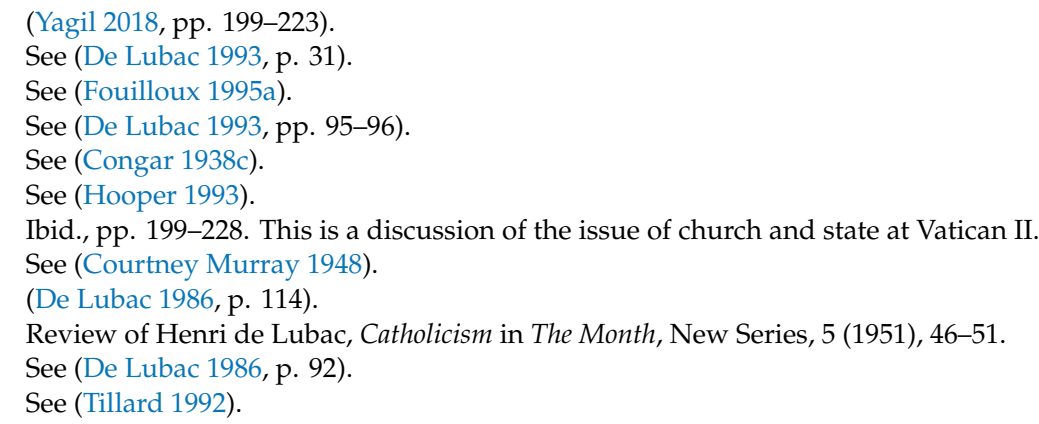


be promoted and deepened each by the other. ${ }^{87}$ De Lubac extends his ecclesial vision beyond the normally fractious relationship between the church and the world to the domain of humanity and to each person individually. He outlines his hypothesis in eschatological terms but without denying its essential this-worldly character: 'To remind man what constitutes his final end is not to tell him something that substantially fails to interest him.... It is rather to illuminate the total meaning of his being by helping him to find and then to interpret the inscription written into his heart by his Creator. ${ }^{\prime 88}$

\subsection{De Lubac's Vision of the Church}

In Méditation sur l'Église, translated into English as The Splendour of the Church, de Lubac sought to formulate a 'total' vision of the Church. ${ }^{89}$ His notion of totality has its origins in scripture and the Fathers of East and West, as may be understood from his 1944 study Corpus Mysticum. This concern was replicated in other ressourcement thinkers, including Congar and Balthasar. Drawing on St Irenaeus, de Lubac argued that the Church is 'one total reality', a 'unique body' in which all the members are engaged in continual interaction..$^{90}$ It should be noted, however, that his attempt to furnish a comprehensive ecclesiology is constrained, since 'the Church is not a this-worldly reality such as lends itself to exact measurement and analysis'. ${ }^{91}$ In some respects, his idea of 'totality' resembles a complex series of crenellations on a medieval fortress, the precise objective of which is to protect and defend the Church and its members. It may be suggested that de Lubac had not succeeded in fully extricating himself from the old defensive model of the Church, as may be seen from his clearly pre-critical view of obedience in Méditation sur l'Église.

The first element of de Lubac's ecclesiology concerns his view of the church as an all-embracing receptacle of Christ's love for the world..$^{92}$ Following St Paul, de Lubac views the church as a communion founded on love that provides a total vista where 'Christ loves us individually but not separately, saying to each of us, as He did to Moses, "I know thee by name" [Ex. 33.12]; He loves us in His Church, for which He shed His blood. ${ }^{93}$ De Lubac stresses the 'total' character of God's gratuitousness: 'The gratuitousness of the supernatural order is true individually and totally'. ${ }^{94}$ Furthermore, he insists on the indispensable link between Christology and ecclesiology. As he writes in his 'Spiritual Testament': 'Without Jesus-Christ, who leads us to God, the Church would be nothing.' Fundamental to his entire vision of the church is the notion of mystery in the New Testament, particularly in the Pauline corpus. For de Lubac, the church is the mysterious spring from which flows the gift of salvation. 'The Church is a mystery because, coming from God and entirely at the service of his plan, she is an organism of salvation, precisely because she relates wholly to Christ and apart from him has no existence, value or efficacy. ${ }^{95}$ Jacques Dupuis (1923-2004) provides an incisive précis of de Lubac's explication of the relationship between Christianity and the world religions, one that includes the vexed question of 'anonymous Christianity':

According to the fulfillment theory which de Lubac makes his own, the mystery of Christ reaches the members of other religious traditions as the divine response to the human aspiration for union with the Divine, but the religious traditions themselves play no role in this mystery of salvation. Henri de Lubac explains that to attribute positive salvific value to them would be tantamount to setting them in competition with Christianity thus obscuring the latter's uniqueness. [... ] According to Henri de Lubac, while it is legitimate to speak

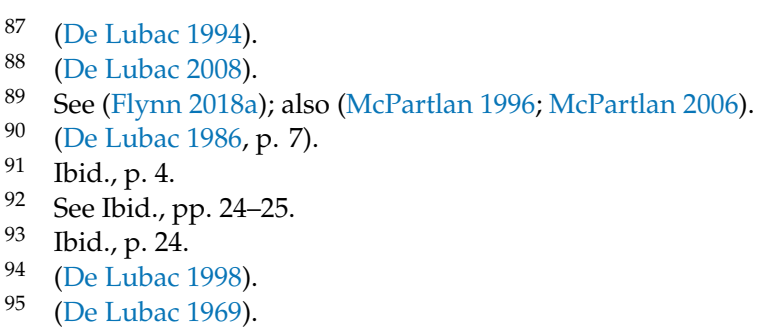


of 'anonymous Christians,' the expression 'anonymous Christianity' is, on the contrary, seriously misleading, for it fails to do justice to the newness of Christianity and its singular character as the way to salvation. ${ }^{96}$

Secondly, we consider de Lubac's view of 'orthodoxy'. This concerns the Church in times of crisis or growth and is, therefore, as important as it is controversial. In moments of error or indecision in past debates, whether on the Trinity, Christology, or grace, one particular mystery inevitably became the standard around which was fought the crucial battle for orthodoxy. In this context, de Lubac, citing St Hilary of Poitiers (De Trinitate, 1. bk. iv, ch. vii), points out that doctrinal formulas undergo necessary revision and are re-cast 'for the greater security of the faith. ${ }^{197}$ While he maintains that 'truth finds its own equilibrium' in such crises, it is noteworthy that he situates the 'crucial battle for orthodoxy' in the context of 'the total Christian mystery'. Indeed, it is within the 'one total reality' of the church's life that he sees a sure safeguard against the threats of 'subjectivism', 'individualism' and 'formal schism'. ${ }^{98}$

Turning to the relationship between the Catholic Church and the world, we reach the pinnacle of de Lubac's design for a 'total' ecclesiology. Along with Congar, he locates the Church at the heart of human life and activity where it acts as a standard bearer of Christ, a source of peace as well as of ferment. ${ }^{99}$ De Lubac proceeds to articulate a vision for social justice. 'The Church is in the world, and by the effect of her presence alone she communicates to it an unrest which cannot be soothed away. She is a perpetual witness of the Christ who came "to shake human life to its foundations", as Guardini puts it, and it is a fact that she appears in the world as a "great ferment of discord". ${ }^{100}$ De Lubac's all-encompassing vision of the church in the modern world resonates with Balthasar's who views the church as being active everywhere. ${ }^{101}$

De Lubac, without denying the apparently 'irresolvable conflicts' inherent in all Church-state relations, proposes a framework of mutuality based on the principle of perpetual 'reciprocal embarrassment'. Fully cognizant of the dangers in every form of separation and union of Church and state, he was only able to resolve the dilemma by recognizing in the Church a 'sign of divine wisdom', while also seeing in the human person, a duality between 'animal' and 'spirit', that is, between the terrestrial and the eternal. De Lubac was resolute in his opposition to any form of absolutism of state or culture in order to avoid any future repetition of totalitarianism and a concomitant quiescence by the Christian Church before the forces of evil. He constructed an integrated spirituality for a 'militant' Church at the heart of the world. ${ }^{102}$

\section{3. 'Faith in Solidarity with Time': Ressourcement and Democracy}

The greatest challenge for the Catholic Church in every age is to read the gospel anew in light of the signs of the times and the needs of the poor, and when everything appears to be in a state of collapse, to set a new course in the service of the public good. As Chenu writes: 'No theology without new birth. Theology, in this sense, is nothing more than faith in solidarity with time. ${ }^{103}$ It is incontrovertible that the greatest and most perilous challenge to ressourcement arose during the 'historically tragic times' when France was occupied by the forces of the German National Socialist regime. This section offers a brief presentation of how leading French ressourcement theologians contributed to the battle against Nazism while also confronting the complicity of the Vichy regime and the quiescence of the majority of French bishops. ${ }^{104}$ If Pius XI had lived long enough, he would have issued his planned

\footnotetext{
(Dupuis 2001).

(De Lubac 1986, p. 8).

Ibid., pp. 5-9.

9 Ibid., p. 6.

100 Ibid., p. 133

101 (Von Balthasar 1991).

102 (De Lubac 1986; Von Balthasar 2013).

103 (Chenu 1937).

104 See (Flynn 2012, pp. 12-16).
} 
new encyclical Humani Generis Unitas, denouncing anti-Semitism much more vociferously than he had in Mit Brennender Sorge. ${ }^{105}$ In the wide range of moral expressions of the regulation of public life, none is better than the moral philosophy that underpins it. The Nazi assault on the French nation met with resistance, including that of the ressourcement scholars, who helped to restore freedom and re-establish a moral authority.

Congar was an implacable enemy of National Socialism. The atmosphere of war and captivity was also a time of profound authenticity when, as a prisoner of war (1941-1945), Congar demonstrated a defiant and obstinate opposition to the enemy. ${ }^{106}$ De Lubac must also be lauded for his strident opposition to anti-Semitism during the Nazi occupation of France, notably, his role as co-editor of the clandestine Cahiers du Témoignage chrétien. ${ }^{107}$ The spirit of the Cahiers was always informed by the fight against anti-Semitism, with de Lubac as one of the principal theologians striving to show the incompatibility between Christianity and Nazism. The Cahiers' profound concern for the soul of France is manifested in its first edition, entitled France, prends garde de perdre ton âme. It provided a ministry to souls and gave a voice to the churches during the painful years of occupation from 1940 to 1944, years of general confusion, military defeat, and breakdown of the institutions of the Third Republic. ${ }^{108}$ During the German occupation of France, de Lubac unambiguously aligned himself with Pope Pius XI and was deeply critical of historians who sought to minimize the significance of the encyclical Mit brennender Sorge. ${ }^{109}$ He was at pains to illustrate the moral courage, diplomacy, and political acuity of the elderly Pope who from 1930 until his death persisted in his combat against Nazism with his courageous battle cry 'Spiritually we are Semites!' ${ }^{110}$

In the context of a discussion of the 'Theological Foundations of the Missions', 111 de Lubac responded to the 'brutal objection' to the church's mission based on race. He repudiated the principal Nazi theoretician of race, Alfred Rosenberg. In a powerful and compelling defence of truth and humanity, de Lubac rallied French Catholics to church and country in defence of the defenceless against the ruthless forces of tyranny:

Christians of France, in the misfortune that has struck our land, we have undoubtedly not been insensitive to the evils that struck the Church at the same stroke. [ ... ] Instead of giving way to despair, we stand by our Church and that her conscience might resound through all our consciences. ${ }^{112}$

In a wartime pamphlet challenging theological accommodations to Nazi ideology, de Lubac movingly restated 'the Christian vocation of France': 'For a spiritual and metaphysical crisis, only a remedy of the same nature is appropriate. [ ... ] Now, the vocation of France is a Christian vocation. [... ] France has also received a certain genius that carries its children either to spread this Christianity around them or to propagate in the world the great human values that we owe to Christianity. ${ }^{113}$

In a letter to his superiors on 25 April 1941, de Lubac described the conquests by Germany as 'an anti-Christian revolution' the aim of which was 'to subjugate the Church' and to impose Nazi methods and ideas. As evidence of this, he pointed to the presence on French soil of concentration camps, the propagation of anti-Semitism and, at the same time, the rise in France of a wave of neo-paganism. ${ }^{114}$

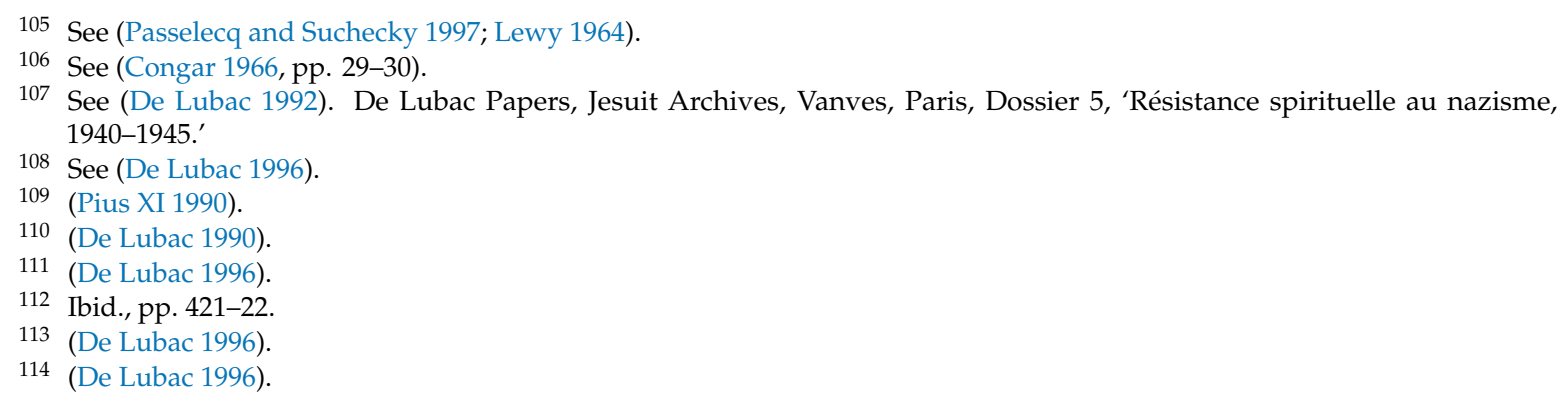


In the course of his letter, he severely criticised church leaders for their apparent blindness to the harshest realities on the ground, while at the same time articulating bewildering platitudes based on self-interest. ${ }^{115}$

Until recently historians have devoted very little attention to the efforts of Jesuit and Dominican priests to assist and to shelter Jews in defiance of the orders of the Vichy regime and/or the occupying German authorities. New archival-based research has recently been published providing an account of the status and treatment of Jews and a detailed account of the Jesuit contribution to their rescue in France (1940-1944). This study reveals, above all, the collaborative nature of the rescue, namely, 'the network', and notes the daring and courageous work of Jesuits and Dominicans in opposition to anti-semitism and racism in the period prior to the commencement of the war. Yagil notes the important work of Amitié chrétienne, an ecumenical group in the diocese of Lyon, established in order to assist victims of the German regime and of Vichy, with Pastor Marc Boegner (1881-1970) and Cardinal Pierre-Marie Gerlier (1880-1965) as honorary patrons. The article documents meticulously the work of the networks of the Jesuits Jean Fleury (Poitiers), Roger Braun (Toulouse), as well as the Networks of Avignon, Tours-Angers, and Paris. The French Jesuit theologian Yves de Montcheuil (1900-1944) is lauded for providing 'the spiritual resistance of the French church to Nazism with major theological impetus and practical assistance. ${ }^{\prime 116}$ Acknowledging that clerical influence was crucial, Yagil concludes her important and original essay with the following remarks: 'The engagement of many men religious in acting for rescue of Jews, was most of the time the direct consequence of their capacity for civil disobedience as individuals to act in different ways. Catholic rescue, it appears, as compared with Protestant rescue often emerged from a culture that included personal friendships with Jews.' She also lauds the role of Pope Pius XI and the Vatican as well as of ordinary French Catholics.

This study also shows the important influence of the encyclical Mit brennender Sorge of March 14, 1937. This well-known encyclical was drafted in a particularly tense environment, with the Vatican engaging in in-depth contemplation on racism and rationalism, in particular in relation to the Holy Office. Alfred Rosenberg's (1893-1946) book was placed in the Index in 1934. [ . . . In fact, in France, for many bishops, priests, and sisters, the encyclical encouraged them to act and rescue Jews, even if Pius xii did not speak openly about it. Christians were encouraged to obey their consciences and disobey rules, in order to rescue Jews. In fact, many Jews were being rescued by Catholic institutions or individuals. ${ }^{117}$

\section{The Future of the Church in a Pluralist Society}

The concluding section of this essay offers reflections on the Catholic Church's future in order to demonstrate the continued relevance and fecundity of the ressourcement vision for the present time. The important work undertaken by Dr A. N. Williams and a group of British and American scholars on ressourcement in 2004 should be noted. 'They met with a view to reflecting upon the significance for our times of that theological movement within Roman Catholic theology in which Congar had played so prominent a part known (in the first instance by its opponents within the Catholic Church) as the nouvelle théologie. ${ }^{118}$ Williams makes an important point regarding what is designated by the term ressourcement, which is a clear reminder of the original vision of this movement. 'The constructive mode of engagement is what is designated by ressourcement, or by the Latin slogan: ad fontes! In both Latin and French, the connotation of the term has to do with refreshment; the Latin fons and the French source can designate a fountain or a spring, a source of living water, while one possible English rendering of the Latin slogan, "back to the sources", can easily evoke no more than a defensive retreat motivated by

\footnotetext{
115 See (De Lubac 1996, pp. 434-45).

116 (Yagil 2018, p. 218); see also (Fouilloux 1995b).

117 (Yagil 2018, p. 222).

118 (Turner 2005).
} 
sheerly antiquarian concerns or theological nostalgia. Ressourcement, in contrast, was not meant to be a return to the sources solely for their own sake, but for the sake of the revitalization of contemporary theology. ${ }^{\prime 19}$ Ressourcement offers a living vision for renewal, dialogue, and constructive engagement with the world in every age. What might a Catholic or Protestant or Orthodox, or Humanist find in this movement today? The following points may be the beginnings of a conversation.

First, ressourcement and Vatican II emerged from the same movement of the Spirit and are effectively like a double-sided painting offering a rich pastoral vision for ecclesial renewal and regeneration, one that is supported by highly robust intellectual and academic foundations. John Macquarrie, writing in 1963, points out that the leading Catholic intellectuals of the era exhibited 'some of the most creative theological thinking of our time. ${ }^{120}$ Just as the leaders of ressourcement were at the heart of the Second Vatican Council and its documents mirrored their thought, so also today, Catholic Church renewal and reform must be both a conciliar and a ressourcement exercise. What is called for, is an openness to the spirit of the council and a new reception of its teaching as well as of ressourcement thought. A new reception of the Council would be facilitated and enhanced by a corresponding series of biographies of the leading ressourcement thinkers that would appeal to a diverse, educated laity, one of the richest fruits of the initial reception of Vatican II, as well as to a highly diffuse secular audience. The ressourcement thinkers were praxis- and mission-oriented intellectuals, academics, and priests whose raison d'etre whether in the trenches of World War II, the factories of the great cities of France, university and seminary lecture halls or college and university chaplaincy services, was to traverse the prevailing cultural, denominational, and generational barriers in order to reveal the light of the gospel in the secular domain. Notwithstanding the difficulties of the time, the French responded to the forceful advances of modernity by representing the challenge of the Church as the living body of Christ actively engaged in human society. Building on this legacy and on the theological methodology of ressourcement, with its vital multidisciplinary, scientific, anthropological, and Christological components that contribute to a more integrated society, the priests and ministers of the Christian Churches today must move forward, aware of the great commission thrust upon them by vocation and by history - what de Lubac refers to as that 'arena of responsibility and purpose'.

Secondly, a highly significant trend in present-day academic theology, one that cuts across denominational boundaries, is the emergent theologies of retrieval which by means of a close re-reading of classic theological texts provides resources that address contemporary theological and pastoral issues. As John Webster remarks: 'All, however, tend to agree that mainstream theological response to seventeenth- and eighteenth-century critiques of the Christian religion and Christian religious reflection needlessly distanced theology both from its given object and from the legacies of its past. ${ }^{\prime 21}$ Darren Sarisky's recent volume, Theologies of Retrieval: An Exploration and Appraisal seeks to correct this imbalance by providing valuable resources, including a retrieval of the riches of ressourcement, to aid all the churches in their mission in the pluralist and secular domains. In my contribution to that work, I was asked to offer insights for a contemporary theology of tradition from the leading exponents of ressourcement. I noted there that at this moment, the Catholic Church is in the midst of a period of tumultuous change as opposing agendas for reform compete for dominance. In the wake of such upheaval, I sought to indicate that in the ressourcement articulation of tradition, many Catholics, as well as members of other Christian denominations or those outside denominational boundaries might recognize an echo of their own hopes. The challenge for Catholic systematic theologians is to formulate a theology of tradition that is sufficiently robust to facilitate a mutually beneficial engagement of church and society and to respond to the ever-changing vicissitudes of faith and worship, service and ministry. In order to be effective, therefore, a retrieval of the ancient tradition

\footnotetext{
119 (Williams 2005, p. 353).

120 (Macquarrie 2001).

121 See (Webster 2007); see also (Webster 2005).
} 
should enable a renewed engagement with Vatican II, so as to contribute to the present program of reform and renewal spearheaded by Pope Francis. ${ }^{122}$ I wish to accentuate de Lubac's contribution because, as indicated in the introduction to this paper, his Sources Chrétiennes series is both popular and relevant to the contemporary situation. Like Congar, he had a dynamic view of tradition: 'What I have more than once regretted in highly regarded theologians, experienced guardians, was less, as others have made out, their lack of openness to the problems and currents of contemporary thought than their lack of a truly traditional mind (the two things are moreover connected). ${ }^{123}$

Thirdly, ressourcement reveals a rich ecumenical vein. This point is elucidated by John Webster in an essay entitled 'Ressourcement theology and Protestantism'. As he writes: 'Until Vatican II, Protestant theologians were generally inattentive to the work of their ressourcement colleagues; since then, much mainstream Protestant theology-especially those strands of English-language, German, and Scandinavian Protestantism with exposure and commitment to the dominant ecumenical theological climate-has come to hold the achievement of ressourcement theology in high esteem. In part, this is because of the remarkable widespread ecumenical adoption of some formulations in ecclesiology and the theology of ministry and sacraments which were also typical of ressourcement theology; in part, it is because of an ecumenical approach to overcoming divisive controversy by returning to common early traditions of doctrine and devotion.' ${ }^{124}$ In a similar vein, Bruno Bürki, who between 1991 and 1998 was Vice-President of the Council of the Swiss Federation of Protestant Churches, points to convergences and challenges in Congar's theology of the laity. He writes: 'Congar's fundamental ecclesiological viewpoint - as articulated in Jalons pour une théologie du laïcat-is so challenging for a reformed concept of the Church, that comparisons must be made, without however neglecting discussion about differences. ${ }^{\prime 125}$ Bürki said he was convinced that Congar's ecclesiological questionings ought to contribute to the reform of worship, Protestant or Reformed. He concludes by enunciating a bold program of ecumenical reform. 'There is no case here anymore for debate about Catholicism or Protestantism, about ecumenism, or even about this or that idea as to what constitutes liturgy, but simply to make an act of faith in the divine presence among us, so as to give glory to the Father by the Son in the Holy Spirit. ${ }^{126}$

In much the same way as ecclesiology provided a vital impetus for renewal in the first half of the twentieth century and at Vatican II, so also at the present time, the turn to the dynamic vision of the Church at the heart of ressourcement may contribute to effective and creative methodologies of reform, and to a newly-vibrant koเv $\omega v i \alpha$ appropriate to the needs of contemporary Christianity. This brings us to the heart of the church and of the ressourcement project. As John McDade points out in a retrospective analysis of ressourcement theology: "The way the church is (its identity) and the way the church has been (its past) form the "double helix" of its genetic identity: a renewed grasp of its history brings about a changed grasp of identity ... This is the thought world of ressourcement: to move between the past and the present in mutually illuminating, corrective, and nourishing ways. ${ }^{\prime 27}$

I close by drawing attention to three key elements of the 'total ecclesiology' 128 of ressourcement:

122 See (Flynn 2017, pp. 173-92).

123 (De Lubac 1993, p. 145).

124 (Webster 2012); in the same volume see also Andrew Louth, 'French ressourcement theology and Orthodoxy: A Living Mutual Relationship', pp. 494-507.

125 (Bürki 2018).

126 Ibid., p. 272.

127 (McDade 2012).

128 The notion of 'totality' (le tout/la totalité) occurs in the thought of some of the leading theologians of ressourcement including, among others, Henri de Lubac, Yves M.J. Congar, and Hans Urs von Balthasar. De Lubac's triadic vision of 'totality' in fact provides a hermeneutical key to interpret his thought on the Church, as noted by commentators including (Boersma 2009; Doyle 1997; Doyle 1999; Flynn [2004] 2016; Pelchat 1998). 


\section{(I) The Realization of the Ecclesiology of Communion}

The greatest challenge for the Catholic Church remains the full realization of the ecclesiology of communion. Congar and de Lubac were the key authors of communion ecclesiology. In theological terms, the most important accomplishment of ressourcement has been the revitalization of the models of the Church as People of God and communio, with Vatican II as the catalyst for renewal. ${ }^{129}$ The elements of the program for Church renewal which Congar articulates through various biblical images form part of a communion ecclesiology that includes conciliarity, collegiality, and reception. He situates the maternal and fraternal dimensions of the Church's nature, seen as perfectly compatible, in the context of communio. It is precisely in the view of the Church as communion that he locates the New Testament notion of kolvovı $\alpha$, which shows clearly that 'there is no union with God without fraternal relations, sharing and community.' ${ }^{130}$ Congar was engaged in ground-breaking work immediately prior to and during Vatican II in order to develop a more properly theological ecclesiology by appropriating the idea of communio. He recognized in this notion a key for the renewal of ecclesiology. Congar's communion ecclesiology accentuates solidarity in love and service accomplished in the sacraments, the communion of bishops, who form the linchpin between the local Churches and the universal Church, and the place of the pope as guardian of the unity of the Church. ${ }^{131}$

Congar, who is best known for his contribution to ecumenicism, views the Catholic principles of ecumenical dialogue in the context of ressourcement and a revitalized communio. By returning to the sources, he contributed to the formulation of an organic concept of the Church that is conciliar, collegial, Christological, pneumatological, and ecumenical. Pneumatology in fact played a decisive role in Congar's communion ecclesiology and helped to restore balance to the Church. In this way, the local and the catholic dimensions, far from being contradictory, are, in fact, suggestive of each other. Such a renewed model of the Church is essentially Trinitarian in nature, 'a community of persons'. Congar's pneumatology, garnered from the ressourcement and dependent on it, provides a point of departure for a new dialogue between Christianity and other religions. ${ }^{132}$

Turning briefly to de Lubac's communion ecclesiology, it is clear that it formed a vital element in his response to a growing spiritual crisis in Europe at the dawn of an era of nihilism and state brutality. In Vocation de la France, he identified the origins of the spiritual and metaphysical crisis affecting European society. He viewed the roots of the crisis in Europe, above all, in the failure of Christians. He proposed a twofold solution, namely, education and a return to the sources, 'un simple mouvement de retour au passé. ${ }^{133}$ The leaders of ressourcement by the heroic witness of their lives and by their writings and conferences against the leaders of German National Socialism and their allies have unwittingly furnished a courageous and effective model of opposition to totalitarianism. For de Lubac, the reconstruction of the Catholic Church and of society would necessitate a Christian/Catholic spirit, which is none other than the spirit of European civilization and French tradition. The crisis in European society and civilization showed de Lubac and other like-minded Catholic intellectuals that the answer to the longings of the human heart is to be found in a profound sense of communion capable of withstanding the threat to humanity posed by aggressive, state-sponsored secularization.

De Lubac's innovative and practical vision of communion, articulated principally in his major texts Catholicisme, Méditation sur l'Église, and Sur les Chemins de Dieu, contributes to the life and mission of the Catholic Church in the present era of religious pluralism. His communion ecclesiology contributed decisively to the renewal of the Church as mystery. The apex of the twentieth-century renewal in Catholic theology is undoubtedly Lumen gentium, the flagship document of Vatican II which bears the imprint of de Lubac's multidimensional vision of the Church encapsulating three key elements:

\footnotetext{
129 See (Flynn 2019, pp. 691-700); also (Flynn 2017).

130 (Congar 1988).

131 (Congar 1962a).

132 See further (Flynn 2018c, pp. 383-407); also (Philibert 2018).

133 (De Lubac 1941, p. 13).
} 
mystery ( $L G \S 1)$, Christology ( $L G \S 6$ ), and Mariology ( $L G \S 8)$. De Lubac unfolds a rich tapestry of the Church as mystery veiled in paradox. The key element of de Lubac's communion ecclesiology is the principle of engagement with the world. As he remarks: 'Yes, even after the splendid achievement of logical, clear exposition that is Lumen Gentium, her most lucid self-definition yet, my meditation is still in the cul-de-sac of mystery. ${ }^{134}$ In his early works, de Lubac sought to re-establish the Catholic Church's essential inter-connectedness to the world and to history. ${ }^{135}$ Through a meticulous study of the historical use of the term corpus mysticum, de Lubac effected a recovery of the relationship between the Church and the Eucharist, the third element of his communion ecclesiology. In Méditation sur l'Église, he describes how the reciprocal relationship between the Church and the Eucharist works for the mutual benefit of the church and the world: 'Thus everything points to a study of the relation between the Church and the Eucharist, which we may describe as standing as cause each to other. Each has been entrusted to the other, so to speak, by Christ; the Church produces the Eucharist, but the Eucharist also produces the Church. [ ... ] But in the last analysis it is the one Body which builds itself up through this mysterious interaction in and through the conditions of our present existence up to the day of its consummation. ${ }^{136}$ De Lubac's treatment of Church and Eucharist, based on a recovery of the insights of the Fathers and of the ancient liturgy on the symbolism of the Eucharistic species, brings us to the heart of his communion theology. The direct consequence of his theology of the Mystical Body is to show anew that Christ and the Holy Spirit are working in the Eucharist to form the Church for the benefit of all. ${ }^{137}$

The Church as communio, is a message and a promise for the 'world of today', which, as Cardinal Walter Kasper has shown, possesses a capacity to build community, develop Church governance, and effect reform. ${ }^{138}$ In an era when Christianity is increasingly marginalized, the laity, a crucial element in the rediscovery of communion ecclesiology, provides the richest resource in the accomplishment of the vision of communion and ressourcement articulated at Vatican II for the mutual enhancement of society, the world, and the churches. As the church seeks to reorient itself and to reform its structures for a credible new evangelization in a deeply secular age, it must look to the gospel anew in contemplation of the divine life present among us.

\section{(II) Oikoumene and the Gospel Hermeneutic of Generosity}

In order to realize the theology of ressourcement articulated at Vatican II, the Christian Churches, while eschewing polemics and all politicization of the gospel, must enunciate the good news with boldness, bearing witness to Christ according to the hermeneutics of generosity, and the gospel

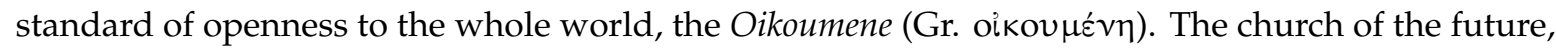
founded on the refreshing, ever-new, ever-vibrant source of Christ and the evangelists, will be a church of hospitality to all, in particular, to the marginalized and the poor; to the young, with their rich potential for positive transformation of the world, its politics and economics; as well as to the weak and vulnerable in their multifarious forms in every age. Historically, the churches have been centres of refuge for all in times of conflict, warfare, and disaster; building on this fecund heritage, the church of tomorrow will be Janus-faced, looking to the riches of the past for a present-day ressourcement, in order to contribute to the prosperity of society in successive generations, both sacred and secular.

\section{(III) Ressourcement and Reconciliation}

The Christian Churches will be the arbitrators of a new gift of reconciliation for the present age dominated by the threat of global, nuclear violence. Without the contemplative church with its

\footnotetext{
134 (De Lubac 1969, p. 3).

135 (De Lubac 1988).

136 (De Lubac 1986).

137 Ibid., p. 108.

138 (Kasper 1986); also (Congar 1965).
} 
inimitable cycle of prayer and sacrifice, the vision of ressourcement remains confined to the realm of theory or mere history. It is only when courageous ambassadors of peace, supported by the church at prayer, dare to cross the borders of political sectarianism and racial prejudice that a new world of justice and equality can begin to take shape. ${ }^{139}$ The way forward must be faithful to the tradition yet open to the arguments of secular culture. As Professor Rolf Hille, formerly Director of Ecumenical Affairs for the World Evangelical Alliance remarks: 'Catholics and Evangelicals alike have the task of carrying out their mission in a new way, connected to an apologetics that addresses the arguments of modern atheism and agnosticism in an intellectually honest and sustainable way. ${ }^{140}$

Funding: This research received no external funding.

Acknowledgments: I express my thanks to Jean-Michel Potin, OP, Archivist of the 'Archive Province Dominicaine de France', Paris; Marie-Gabrielle Lemaire, Archivist of the 'Centre d'Archives et d'Etudes Cardinal Henri de Lubac', University of Namur, Belgium; and Dries Bosschaert, Archivist of the 'Centre for the Study of the Second Vatican Council', the Catholic University of Louvain (KU, Leuven); I also thank anonymous reviewers and Leo Declerck (KU Leuven) for comments on an earlier draft of this paper.

Conflicts of Interest: The author declares no conflict of interest.

\section{References}

Alberigo, Giuseppe. 1985. Christianisme en tant qu'histoire et "Théologie Confessante". In Une École de Théologie: Le Saulchoir. Edited by Marie-Dominique Chenu. Paris: Cerf, pp. 9-35.

Aubert, Roger. 1954. La Théologie Catholique au Milieu du XXe siècle. Tournai: Casterman.

Beal, Rose M. 2014. Mystery of the Church, People of God: Yves Congar's Total Ecclesiology as a Path to Vatican II. Washington: Catholic University of America Press.

Bedouelle, Guy. 1999. Architecture et vie Dominicaine au XXe Siècle. In Mémoire Dominicaine: Histoire, Documents, Vie Dominicaine 14. Paris: Cerf.

Bedouelle, Guy. 2010. The Cornerstone: Christian Faith and Modern Culture in Dialogue. In Ressourcement Thomism: Sacred Doctrine, the Sacraments, and the Moral Life. Edited by Reinhard Hütter. Translated by Martha Ritchie, and Matthew Levering. Washington: Catholic University of America Press, pp. XIII-XV.

Boersma, Hans. 2009. Nouvelle Théologie and Sacramental Ontology: A Return to Mystery. Oxford: Oxford University Press.

Boirel, François. 1995. Grandes figures catholiques du xx ${ }^{\mathrm{e}}$ Siècle: L'exception catholique française (1870-1965). In Petite Encyclopédie Moderne du Christianisme. Edited by Georges Carpentier and Charles Ehlinger. Paris: Desclée de Brouwer.

Boland, Vivian. 2014. Saint Thomas Aquinas. London: Bloomsbury.

Bouyer, Louis. 1947. Le Renouveau des études patristiques. La Vie Intellectuelle 15: 6-25.

Brown, Stewart J., and Peter Nockles, eds. 2017. The Oxford Handbook of the Oxford Movement. Oxford: Oxford University Press.

Bürki, Bruno. 2018. The Church's Sacramental Celebration of the Easter Mystery. In Yves Congar: Theologian of the Church. Edited by Gabriel Flynn. Leuven: Peeters Publishers, New and Expanded Edition, pp. 251-72.

Chenu, Marie-Dominique. 1937. Une École de Théologie: Le Saulchoir. In Ressourcement Theology: A Sourcebook. Translated by Patricia Kelly in Her Forthcoming Work. London: Bloomsbury.

Chenu, Marie-Dominique. 1961. La fin de l'ère Constantinienne. In Un Concile Pour Notre Temps. Edited by Jean-Pierre Dubois-Dumée. Paris: Cerf, pp. 59-87.

Chenu, Marie-Dominique. 1965. A Conversation with Père Chenu. Translated by Joseph P. Philibert. Dominicana Journal. Available online: https://www.dominicanajournal.org/dominicana-1916-1968-archive/dominicana502-summer-1965-2/ (accessed on 20 June 2019).

139 In Northern Ireland, the Clonard Monastery (Redemptorist Order) in West Belfast is such a centre for reconciliation which hosted the peace talks leading to the 1998 Good Friday Agreement while the Holy Cross Monastery (Benedictine Order) in Rostrevor, County Down, is an ecumenical centre of renewal and evangelization serving all the Christian denominations of the province. See (Wells 2005; Nolan 2011).

140 (Hille 2018). 
Chenu, Marie-Dominique. 1990. Regard sur cinquante ans de vie religieuse. In L'Hommage Differéau Père Chenu. Paris: Cerf.

Chenu, Marie-Dominique. n.d. 'La Contemplation'. Paris: APDF, pp. 1-6. (2).

Congar, Yves. 1934. L'Actualité de Kierkegaard. La Vie Intellectuelle 32: 9-36.

Congar, Yves. 1938a. The Reasons for the Unbelief of our Time: A Theological Conclusion', Part I. Integration, 13-21, (August 1938).

Congar, Yves. 1938b. The Reasons for the Unbelief of our Time: A Theological Conclusion, Part II. Integration, 10-26, (December 1938).

Congar, Yves. 1938c. L'Esprit des Pères d'après Moehler. Supplément à la 'Vie Spirituelle' 55: 1-25.

Congar, Yves. 1939. Autour du renouveau de l'ecclésiologie: la collection “Unam Sanctam”. La Vie Intellectuelle 51: 9-32.

Congar, Yves. 1961. The Wide World My Parish: Salvation and Its Problems. Translated by Donald Attwater. London: Darton, Longman \& Todd.

Congar, Yves. 1962a. De la communion des Églises à une ecclésiologie de l'Église universelle. In L'Épiscopat et l'Église universelle. Edited by Y. Congar and B.-D. Dupuy. Paris: Cerf, pp. 227-60.

Congar, Yves. 1962b. The Council in the Age of Dialogue. Translated by Barry N. Rigney. Cross Currents 12: 144-51.

Congar, Yves. 1965. La Collégialité Episcopale. Paris: Cerf.

Congar, Yves. 1966. Dialogue between Christians: Catholic Contributions to Ecumenism. Translated by Philip Loretz. London: Geoffrey Chapman.

Congar, Yves. 1972a. My Path-Findings in the Theology of Laity and Ministries. Jurist 32: 169-88.

Congar, Yves. 1972b. Renewal of the Spirit and Reform of the Institution. Translated by John Griffiths. Concilium 73: 39-49.

Congar, Yves. 1978. Église Catholique et France Moderne. Paris: Hachette.

Congar, Yves. 1984. Tendances actuelles de la pensée religieuse. Cahiers du Monde Nouveau 4: 33-50.

Congar, Yves M.-J. 1985a. The Brother I have known. Translated by Boniface Ramsey. The Thomist 49: $495-503$. [CrossRef]

Congar, Yves. 1985b. Lay People in the Church: A Study for a Theology of Laity. Translated by Donald Attwater. London: Geoffrey Chapman, Westminster: Christian Classics.

Congar, Yves. 1988. Called to Life. Slough: St Paul, New York: Crossroad.

Congar, Yves. 2011. True and False Reform in the Church. Translated by Paul Philibert. Collegeville: Liturgical Press. Courtney Murray, John. 1948. Sources Chrétiennes. Theological Studies 9: 250-55.

D'Ambrosio, Marcellino. 1991. Ressourcement theology, aggiornamento, and the hermeneutics of tradition. Communio 18: 530-55.

Daniélou, Jean. 1946. Les orientations présentes de la pensée religieuse. Études 249: 5-21.

De Lubac, Henri. 1941. Vocation de la France. Coll. Le Témoignage chrétien. Le Puy: Mappus.

De Lubac, Henri. 1969. The Church: Paradox and Mystery. Translated by James R. Dunne. Shannon: Ecclesia Press.

De Lubac, Henri. 1986. The Splendour of the Church, 3rd ed. Translated by Michael Mason. London: Sheed \& Ward.

De Lubac, Henri. 1988. Catholicism: Christ and the Common Destiny of Man. Translated by Lancelot C. Sheppard, and Elizabeth Englund. San Francisco: Ignatius.

De Lubac, Henri. 1990. Christian Resistance to Anti-Semitism. San Francisco: Ignatius Press.

De Lubac, Henri. 1992. La question des évêques sous l'occupation. Revue des Deux Mondes 1992: 67-82.

De Lubac, Henri. 1993. At the Service of the Church: Henri de Lubac Reflects on the Circumstances that Occasioned His Writings. Translated by Anne Elizabeth Englund. San Francisco: Ignatius Press.

De Lubac, Henri. 1994. Corpus Mysticum: L'Eucharistie et L'église au Moyen Âge: Étude Historique. Paris: Aubier.

De Lubac, Henri. 1996. Theology in History. Translated by Anne Englund Nash. San Francisco: Ignatius Press.

De Lubac, Henri. 1998. The Mystery of the Supernatural. Translated by Rosemary Sheed. New York: Crossroad Publishing.

De Lubac, Henri. 2008. The Total Meaning Of Man And The World. Translated by David Schindler. Communio 35: 613-41.

Declerck, Leo. 2015. Mgr J. Willebrands et la Conférence Catholique Pour les Questions OEcuméniques. Ses Archives à Chevetogne. Introduction by Peter De Mey. Instrumenta Theologica 39. Leuven: Peeters. 
Dousse, Jean-Bernard, and Bernard Hodel, eds. 2000. Les Fraternités Laïques et la Mission de l'Ordre des Prêcheurs, Les Textes Officiels 1946-1998. Paris: Cerf.

Doyle, Dennis M. 1997. Journet, Congar, and the Roots of Communion Ecclesiology. Theological Studies 58: 461-79. [CrossRef]

Doyle, Dennis M. 1999. Henri de Lubac and the Roots of Communion Ecclesiology. Theological Studies 60: 209-27. [CrossRef]

Dupuis, Jacques. 2001. Toward a Christian Theology of Religious Pluralism, 3rd ed. Maryknoll: Orbis Books.

Duquesne, Jacques, and Marie-Dominique Chenu. 1975. Jacques Duquesne Interroge le Père Chenu: 'un Théologien en Liberté'. Paris: Centurion.

Duval, André. 1980. Une Organisation au Service de la Liberté. In Dominicains: L'ordre des Prêcheurs Présenté par Quelques-uns D'entre eux. Edited by Alain Quilici. Paris: Cerf, pp. 177-87.

Fields, Stephen M. 2014. Ressourcement and the Retrieval of Thomism for the Contemporary World. In Ressourcement: A Movement for Renewal in Twentieth-Century Catholic Theology, 2nd ed. Edited by Gabriel Flynn and Paul D. Murray. Oxford: Oxford University Press, pp. 355-71.

Figoureux, Loïc. 2017. Henri de Lubac et le Concile Vatican II (1960-1965). Bibliothèque de la Revue D'Histoire Ecclésiastique, 102. Louvain-La-Neuve: Brepols.

Flynn, Gabriel. 2003. Mon journal du Concile: Yves Congar and the Battle for a Renewed Ecclesiology at the Second Vatican Council. Louvain Studies 28: 48-70. [CrossRef]

Flynn, Gabriel. 2012. The Twentieth-Century Renaissance in Catholic Theology. In Ressourcement: A Movement for Renewal in Twentieth-Century Catholic Theology. Edited by Gabriel Flynn and Paul D. Murray. Oxford: Oxford University Press, pp. 1-19.

Flynn, Gabriel. 2016. The Question of Unbelief Today. In Yves Congar's Vision of the Church in a World of Unbelief. Oxford: Routledge, pp. 221-28. First published 2004.

Flynn, Gabriel. 2017. Tradition I: Insights from Ressourcement for the Contemporary Christian Church. In Theologies of Retrieval: An Exploration and Appraisal. Edited by Darren Sarisky. London: Bloomsbury, pp. 173-91.

Flynn, Gabriel. 2018a. Henri de Lubac. In The Oxford Handbook of Ecclesiology. Edited by Paul Avis. Oxford: Oxford University Press, pp. 409-29.

Flynn, Gabriel. 2018b. Yves Congar: Theologian of the Church. Leuven: Peeters Publishers, New and Extended Edition. Flynn, Gabriel. 2018c. Yves Congar. In The Oxford Handbook of Ecclesiology. Edited by Paul Avis. Oxford: Oxford University Press, pp. 383-407.

Flynn, Gabriel. 2019. Ressourcement and Theologies of Communion. In The Oxford Handbook of Catholic Theology. Edited by Lewis Ayres and Medi Ann Volpe. Oxford: Oxford University Press, pp. 683-700.

Flynn, Gabriel. Forthcoming. Theological Renewal in the First Half of the Twentieth Century. In The Cambridge Companion to Vatican II. Edited by Richard Gaillardetz. Cambridge: Cambridge University Press.

Flynn, Gabriel, and Paul D. Murray, eds. 2014. Ressourcement: A Movement for Renewal in Twentieth-Century Catholic Theology, 2nd ed. Oxford: Oxford University Press.

Folliet, Joseph. 1972. Le Temps de L'Angoisse et de la Recherche, Les Chrétiens au Carrefour, 3, 2nd ed. Paris: Chronique Sociale de France.

Fouilloux, Étienne. 1995a. La Collection 'Sources Chrétiennes': Éditer les Pères de l'Église au XXe Siècle. Paris: Cerf. Fouilloux, Étienne. 1995b. Yves de Montcheuil: Philosophe et Théologien Jésuite (1900-1944). Paris: Médiasèvres.

Fouilloux, Étienne. 1998. Une Église en Quête de Liberté: La Pensée Catholique Française Entre Modernisme et Vatican II (1914-1962), Anthropologiques. Paris: Declée de Brouwer.

Fouilloux, Étienne. 2004. "Nouvelle théologie" et théologie nouvelle (1930-1960). In L'histoire Religieuse en France et Espagne. Edited by Benoît Pellistrandi. Collection de la Casa Velázquez, 87. Madrid: Casa de Velázquez, pp. 411-25.

Fouilloux, Étienne, and Bernard Hours, eds. 2005. Les Jésuites à Lyon XVI $-X X^{e}$ Siècle. Lyon: ENS Editions.

Fouilloux, Étienne. 2012. A New "Lyon School" (1919-1939)? In Ressourcement: A Movement for Renewal in Twentieth-Century Catholic Theology. Edited by Gabriel Flynn and Paul D. Murray. Oxford: Oxford University Press, pp. 83-94.

Fouilloux, Étienne, and Yves Congar. 2001. Journal d'un Théologien (1946-1956), 2nd ed. Edited by Étienne Fouilloux. Paris: Cerf.

Frisque, Jean. 1970. L'ecclésiologie au XXe siècle. In Bilan de la Théologie du XX Siècle. Edited by Robert Vander Gucht and Herbert Vorgrimler. Paris: Casterman, pp. 412-56. 
Furnal, Joshua. 2016a. Catholic Theology after Kierkegaard. Oxford: Oxford University Press.

Furnal, Joshua. 2016b. Kierkegaard's Catholic Reception and the Legacy of Vatican II. Toronto Journal of Theology 32: 17-23. [CrossRef]

Garrigou-Lagrange, Réginald. 1946. La nouvelle théologie où va-t-elle. Angelicum 23: 126-45.

Geffré, Claude. 1990. L'hommage Différé au Père Chenu. Paris: Cerf.

Godin, Henri, and Yvan Daniel. 1950. La France: Pays de Mission? 7th ed. Paris: Cerf.

Granfield, Patrick. 1967. Theologians at Work. New York: Macmillan, London: Collier-Macmillan.

Hille, Rolf. 2018. Public Witness in Secular and Multi-Religious Societies: The Dialogue between the World Evangelical Alliance and the Pontifical Council for Promoting Christian Unity. Evangelical Review of Theology 42: 131-35.

Hooper, J. Leon. 1993. Catholic Struggles with Pluralism: John Courtney Murray. Louisville: Westminster/John Knox Press.

Kaplan, Grant. 2016. The Renewal of Ecclesiological Studies: Chenu, Tübingen, and Theological Method in Optatam Totius. Theological Studies 77: 567-92. [CrossRef]

Kasper, Walter. 1986. Church as Communio. Communio 3: 100-17. [CrossRef]

Kelly, Patricia. 2016. Taking Theology to Work: Ressourcement Theology and Industrial Work in Interwar France and Belgium. Unpublished Ph.D. thesis, Durham University, UK. Available online: http://etheses.dur.ac.uk/11819/ (accessed on 23 October 2019).

Kerr, Fergus. 2007. Twentieth-Century Catholic Theologians. Oxford: Blackwell.

Labourdette, Marie-Michel. 1946. La Théologie et ses sources. Revue Thomiste 46: 353-71.

Lacoste, Jean-Yves. 2009. Histoire de la Théologie. Paris: Éditions du Seuil.

Leprieur, François. 1989. Quand Rome Condamne: Dominicains et Prêtres-Ouvriers. Paris: Cerf.

Leprieur, François. 1999. France in 1953-1954: Do the baptised have rights? The Worker-Priest Crisis. New Blackfriars 80: 384-96. [CrossRef]

Levering, Matthew. 2017. An Introduction to Vatican II as an Ongoing Theological Event. Washington: Catholic University of America Press.

Lewy, Guenter. 1964. The Catholic Church and Nazi Germany. London: Weidenfeld \& Nicolson.

Macquarrie, John. 2001. Twentieth-Century Religious Thought, 5th ed. London: SCM Press.

Martin Newsome, Jennifer. 2017. A Roman Catholic Theology of Ressourcement, Theologies of Retrieval: An Exploration and Appraisal. In Theologies of Retrieval: An Exploration and Appraisal. Edited by Darren Sarisky. London: Bloomsbury, pp. 81-100.

Mayeur, Jean-Marie. 1966. La Séparation de l'Église et d'Etat. Paris: Julliard.

McDade, John. 2012. Ressourcement in Retrospect. In Ressourcement: A Movement for Renewal in Twentieth-Century Catholic Theology. Edited by Gabriel Flynn and Paul D. Murray. Oxford: Oxford University Press, pp. 508-22.

McPartlan, Paul. 1996. The Eucharist, the Church and evangelization: The influence of Henri de Lubac. Communio 23: 776-85.

McPartlan, Paul. 2006. The Eucharist Makes the Church: Henri de Lubac and John Zizioulas in Dialogue, 2nd ed. Fairfax: Eastern Christian Publications.

Mettepenningen, Jürgen. 2010. Nouvelle Théologie-New Theology: Inheritor of Modernism, Precursor of Vatican II. London: Bloomsbury Publishing.

Murphy, Francesca Aran. 2004. Art and Intellect in the Philosophy of Étienne Gilson. Columbia: University of Missouri Press.

Nolan, Mark-Ephrem M. 2011. Fresh Springs from an Ancient Well: The Story of the Rostrevor Benedictines. Belfast: Octagon.

Passelecq, Georges, and Bernard Suchecky. 1997. The Hidden Encyclical of Pius XI. Translated by Steven Rendall. New York: Harcourt Brace.

Pelchat, Marc. 1998. L'ecclésiologie de Henri de Lubac. Roma: P.U.G.

Philibert, Paul J. 2002. Translator's Introduction in Marie-Dominique Chenu. In Aquinas and His Role in Theology. Collegeville: Liturgical Press, pp. V-VIII.

Philibert, Paul. 2018. Congar's Ecclesiastical Subtext: Intransigent Conservatism. In Yves Congar: Theologian of the Church. Edited by Gabriel Flynn. Leuven: Peeters Publishers, New and Expanded Edition, pp. 327-42. 
Pius XI, Pope. 1990. Mit brennender Sorge: Encyclical of Pope Pius XI on the Church and the German Reich (March 14, 1937). In The Papal Encyclicals 1903-1939, iii. Edited by Claudia Carlen. 5 vols. Raleigh: Pierian, pp. 525-35.

Potworowski, Christophe. 2001. Contemplation and INCARNATION: The Theology of Marie-Dominique Chenu. Montreal: McGill-Queen's University Press.

Puyo, Jean. 1975. Jean Puyo Interroge le Père Congar: une vie Pour la Vérité. Paris: Centurion.

Ravitch, Norman. 1990. The Catholic Church and the French Nation 1589-1989. London: Routledge.

Riches, Aaron. 2017. Henri de Lubac and the Second Vatican Council. In TET Clark Companion to Henri de Lubac. Edited by Jordan Hillebert. London: Bloomsbury, pp. 121-56.

Routhier, Gilles. 2011. Introduction. In La Théologie Catholique Entre Intransigeance et Renouveau: La Réception des Mouvements Préconcilaires à Vatican II. Edited by Gilles Routhier, Philippe J. Roy and Karim Schelkens. Louvain-la-Neuve and Leuven: Brepols, pp. 5-9.

Scarisbrick, J. J. 2018. An Historian's Reflections on Yves Congar's Mon journal du Concile. In Yves Congar: Theologian of the Church. Edited by Gabriel Flynn. Leuven: Peeters, New and Extended Edition, pp. 343-69.

Schelkens, Karim. 2017. Vatican II in Ireland, Fifty Years On. Essays in Honour of Pcidraic Conway. Revue D'Histoire Ecclésiastique 112: 467-69.

Siefer, Gregor. 1964. The Church and Industrial Society: A Survey of the Worker-Priest Movement and Its Implications for the Christian Mission. Translated by Isabel, and Florence McHugh. London: Darton, Longman and Todd.

Suenens, Léon-Joseph. 1968. Coresponsibility in the Church. Translated by Francis Martin. London: Burns \& Oates.

Suhard, Emmanuel. 1948. Growth or Decline?: The Church Today. Translated by James A. Corbett. Montreal: Fides Publishers.

Sullivan, John. 2018. The Oxford Handbook of John Henry Newman. Edited by Frederick D. Aquino and Benjamin J. King. Oxford: Oxford University Press, pp. 538-56.

Tillard, Jean-Marie R. 1992. Church of Churches: The Ecclesiology of Communion. Translated by Rowland Charles De Peaux. Collegeville: Liturgical Press.

Turner, Denys. 2005. Guest Editorial. International Journal of Systematic Theology 7: 343-45. [CrossRef]

Vangu, Emmanuel. 2007. La Théologie de Marie-Dominique Chenu: Réflexion sur une Méthodologie Théologique de L'intégration Communautaire. Paris: L'Harmattan.

Visser 't Hooft, Willem Adolph. 2001. Le développement des relations entre Rome et le mouvement œcuméique. In W. A. Visser 't Hooft, Pionnier de L'œcuménisme: Genève-Rome. Edited by Jacques Maury. Paris: Cerf, pp. 43-92.

Von Balthasar, Hans Urs. 1975. Prayer, 2nd ed. Translated by A. V. Littledale. London: SPCK.

Von Balthasar, Hans Urs. 1991. The Theology of Henri de Lubac: An Overview. Translated by Joseph Fessio and Michael M. Waldstein. San Francisco: Ignatius Press.

Von Balthasar, Hans Urs. 2013. The Theology of Henri de Lubac. San Francisco: Ignatius Press.

Webster, John. 2005. Purity and Plenitude: Evangelical Reflections on Congar's Tradition and Traditions. International Journal of Systematic Theology 7: 399-413. [CrossRef]

Webster, John. 2007. Theologies of Retrieval. In The Oxford Handbook of Systematic Theology. Edited by John Webster, Kathryn Tanner and Iain Torrance. Oxford: Oxford University Press, pp. 583-99.

Webster, John. 2012. Ressourcement Theology and Protestantism. In Ressourcement: A Movement for Renewal in Twentieth-Century Catholic Theology. Edited by Gabriel Flynn and Paul D. Murray. Oxford: Oxford University Press, pp. 482-94.

Wells, Ronald. 2005. Friendship Towards Peace: The Journey of Ken Newll and Gerry Reynolds. Dublin: Columba Press. Williams, A. N. 2005. The Future of the Past: The Contemporary Significance of the Nouvelle Théologie. International Journal of Systematic Theology 7: 347-61. [CrossRef]

Williams, A. N. 2018. Congar's Theology of the Laity. In Yves Congar: Theologian of the Church. Edited by Gabriel Flynn. Leuven: Peeters Publishers, New and Expanded Edition. pp. 133-57.

Wittstadt, Klaus. 1995. On the eve of the Second Vatican Council (July 1-October 10, 1962). In History of Vatican II: Announcing and Preparing Vatican Council II. Edited by Giuseppe Alberigo; English version edited by Joseph A. Komonchak. Maryknoll: Orbis, Louvain: Peeters, vol. 5, pp. 405-500. 
Yagil, Limore. 2018. Rescue of Jews in France 1940-1944: The Jesuit Contribution. Journal of Jesuit Studies 5: 199-233. [CrossRef]

Zamagni, Gianmaria. 2011. Re(dis)covering Humanity: The Catholic Church and Human Rights. In The Quest for a Common Humanity: Human Dignity and Otherness in the Religious Traditions of the Mediterranean. Edited by Katell Berthelot and Matthias Morgenstern. Numen Book Series-Studies in the History of Religions, 134. Leiden: Brill, pp. 349-61. 